\title{
The Effect of Decision Making and Value of Family Transaction with its Environment on Family Social Strength
}

\author{
Lutfiah Syahidah $^{1 *}$, Euis Sunarti \\ ${ }^{1,2}$ Department Family and Consumer Science, Faculty of Human Ecology, IPB \\ University, Bogor 16680, Indonesia \\ *Corresponding author: lutfiahsyahidah@gmail.com
}

\begin{abstract}
Family social strength positively correlated with family transactions and its environment. This study aimed to examine decision making and the value of family transactions with its environment towards family social strength. The study used a cross-sectional design involving 120 intact families who have children under five years old and selected by stratified disproportional random sampling according to their residence (FP village and non-FP village) in Village Muara, Pasirjaya, West Bogor. The analysis showed that family social strength had a positive correlation with wife's education level, decision making, and value of the family transaction otherwise family strength had a negatively correlated with the number of family and children. The result of the regression tests showed that decision making and the value of the family transaction had a positive effect on family social strength, but the number of children had a negative influence on family social strength. The regression tests showed either with family or without family characteristics, decision making and transaction value had a positive effect on family social strength. Contrarily, family characteristics on the number of children, both with and without the dimensions of decision making and transaction value consistently had an adverse effect on family social strength.
\end{abstract}

keyword: decision making, family environment, family social strength, value transaction

\begin{abstract}
Abstrak
Ketahanan sosial keluarga berkaitan dengan transaksi keluarga dengan lingkungannya. Penelitian ini bertujuan untuk menganalisis pengambilan keputusan dan nilai transaksi keluarga dengan lingkungannya terhadap ketahanan sosial keluarga. Penelitian ini menggunakan desain cross sectional melibatkan 120 keluarga utuh yang memiliki anak balita. Dipilih secara stratified disproportional random sampling menurut tempat tinggal (Kampung KB dan bukan Kampung KB) di Kampung Muara, Kelurahan Pasirjaya, Bogor Barat. Hasil uji korelasi menunjukkan hubungan positif antara ketahanan sosial keluarga dengan lama pendidikan istri, pengambilan keputusan, dan nilai transaksi keluarga dengan lingkungannya, namun berkorelasi negatif dengan jumlah anggota keluarga dan jumlah anak. Hasil uji regresi menunjukkan baik dengan maupun tanpa karakteristik keluarga, secara konsisten pengambilan keputusan dan nilai
\end{abstract}


transaksi keluarga dengan lingkungannya berpengaruh positif terhadap ketahanan sosial keluarga. Namun, karakteristik keluarga pada jumlah anak, baik dengan maupun tanpa dimensi pengambilan keputusan dan nilai transaksi secara konsisten berpengaruh negatif terhadap ketahanan sosial keluarga.

Kata kunci: ketahanan sosial keluarga, lingkungan keluarga, nilai transaksi, pengambilan keputusan

\section{Introduction}

The Indonesian Information and Communication Technology (ICT) Development Index shows that the level of establishment of ICT and the digital gap in 2016 increased by 0.46 percent. The rapid development of technology inflict social changes and indicate the need to strengthen the family. Family strength is essential for it is the individuals primary place to upskill and socialize in order to obtain the desired well-being. It is the ability of the family to manage owned resources and manage problems (Sunarti, 2001). It identifies the need for families to carry out standard information and actions taken in receiving information from technological and social aspects that the desired strength can be attained. The stronger family become will be the basis for the progress of a nation (Megawangi \& Sunarti, 2003).

Social strength is one of the components of family strength. It is the force of family in practicing religious values, upkeep the relation and commitment, goal setting, effective communication, division and acceptance of roles, encouragement to progress when contending family problems and in having healthy relationships (Sunarti, 2001). Overall the family is part of the life systems and interacts with a diverse environment (Sunarti, 2007). The family carries out various transactions with the environment in order to carry out functions and roles in the social environment. The result of Maryanti (2016), shows that social support in the environment influenced the family social strength. It shows the need for families to build an environment that can enable them to have a quality life.

Family ecology examines the link between families with its diverse environment. Family transactions with the environment become one way for the family to achieve well-being for all members. There are four processes of family transaction's model with its environment, namely acceptance or perception, spacing, valuing, and decision making (Melson, 1980). This research examines the decision making and transaction value to see the actions taken by the family and see the importance of information that the family gets about the environment. Decision-making becomes an inseparable part of life as a reflection of perceptions, needs, and values in the family, as well as a reflection of patterns of interaction in the family (Melson, 1980). According to Kusumo et al. (2009), the daily family decision making is carried out to achieve life goals and as part of family coping strategies. Decision making that externally made by family is undertaken towards the environment to achieve social strength. The value of family transactions with the environment is an integral concept of the family decision process. Value as determinants of action in deciding information to be used in daily life (Melson, 1980). Also, a value is a basis in which families continue to exist even though obstacles and vulnerabilities threaten their lives (Sunarti, 2013). Values form the basis of life for each family member to achieve quality and prosperous individuals (Sunarti, 2015). Based on this, the goal of this study to (1) identify the characteristics of family, 
decision-making, family transaction values with its environment, and family social strength; and (2) analyze the influence of family characteristics, decision-making, and family transaction value with its environment on family social strength.

\section{Methods}

This research was carried out collectively based on "Internal Interactions and External Family Transactions Relating to Child Development and Family Well-being" in a cross-sectional study. The study was located in Pasirjaya Subdistrict, West Bogor, West Java which was chosen purposively with the consideration its density populated conditions. Moreover, Subdistrict is a model village noted by FP primarily in Bogor area.

The data was collected from March to April 2018. The sample in this study was 120 families who have a toddler. Family with children under five (1-5 years old) were chosen considering, it is the family's stage has a huge role in building a sufficient environment for child development. The sampling technique used stratified disproportional random sampling.

Decision-making is the ultimate control process in the family requiring their interaction with its environment. Transaction value is an individual interpretation of right and wrong and righteous and bad over interests (important-not important). The value of the family system fathoms a part that is inseparable from the family strength. Family social strength is the ability of a family to manage non-physical resources, a good coping mechanism, orientation towards religious values, effective communication, and always maintaining a social relationship.

The questionnaire of decision-making was developed from Kusumo, Sunarti, and Pranadji (2009) using 19 statements consisting of economic and social community dimensions with Cronbach's alpha 0.779 . The questionnaire of family transaction values with its environment was referenced from Sunarti (2017) using 20 statements composed of community cohesion, social capital, social strength, obedient, caring, attention and protection dimensions with Cronbach's alpha 0.906.

The questionnaire of social security is referenced and modified from Sunarti (2001), taking the dimensions of self-esteem and social life consisting of 10 statements with Cronbach's alpha 0.697. Variables of decision-making and family social strength consist of four answer scales $(0=$ never; $1=$ sometimes; $2=$ often; $3=$ always $)$. The scale of the answers to the transaction value uses the semantic scale 1-7 (intensity from the lowest to the highest). The results of the study were made in a low category (033.3), moderate (33.4-66.7), and high (66.8-100) based on Walsh (2002).

Data analyses were using Microsoft Excel for Windows and SPSS 22 for Windows programs. Analyzed descriptively covering standard deviation, maximum and minimum values, and mean. Inference analyses included correlation and linear regression test. A correlation test was conducted to analyze the relationship between family characteristics, decision making, family transaction value with its environment, and family social strength. Regression tests were conducted to analyze the influence of family characteristics, decision making, and family transaction value with the environment on family social strength. 


\section{Findings}

\section{Family Characteristics}

The results indicate that the average age of wife and husband is 31.5 years and 36.5 years. The average length of education pursued by wife and husband is 8.4 years and 9.1 years. The average total per capita family income per month is Rp. 614844 . The average family size is four people and categorized as small families. The results of the study also showed that the marriage duration of couples averaging 10 years had long settled in Pasirjaya Subdistrict on average 19 years.

\section{Family Decision-Making with Its Environment}

Family decision-making involves interaction and communication between family members and direct actions to attain individual and family goals (Melson, 1980).

Table 1 Average of family decision-making with its environment index

\begin{tabular}{lr}
\hline Statement & Index \\
\hline Economic dimension & 42.4 \\
\hline Prefer to buy from the neighbor & 73 \\
Help promote neighbor's products & 26.9 \\
Looking for price information of products/services with the neigborhood & 46.6 \\
Help to sell the villager's product by the activities that followed & 13.3 \\
Cooperate with the surroundings to increase the income & 25.2 \\
Determine the use of family planning tools as a contribution to manifest FP & 74.7 \\
Village & 37.5 \\
Use savings to start a business in the nearest neighborhood & 56.7 \\
\hline Social community dimension & 50.2 \\
Following community activities & 69.4 \\
Discuss with the community & 52.5 \\
Help one another & 65 \\
Aware of environmental safety & 54.7 \\
Make a celebration with neighbors & 43.3 \\
Contributing energy and mind to deliberate advancing the region & 52.7 \\
Sharing food/clothing/goods to neighbors & 52.2 \\
Heeding for the neighbors & 69.4 \\
Participate in maintaining the cleanliness of the environment & 48.6 \\
Advise the neighbors if needed & 40.5 \\
Building a networking relationship & 82.5 \\
Allow children to play with their environment & 56.7 \\
\hline Family decision-making total & \\
\hline
\end{tabular}

Based on the results of the research, in Table 1 shows that the average index of family decision-making with its environment in the medium category (51.4\%). The social community dimension is the highest dimension $(56.7 \%)$ with the highest achievement statement "allow children to play with their environment without distinguishing social status" $(82.5 \%)$, and the lowest on statements of "build networking with the environment" (40.5\%). Even so, the results indicate the need for families to contribute more to their surroundings in building cooperation and working together. In view the fact that the social community dimension emphasizes the process and action of the family to participate in the environment actively. The economic dimension emphasizes the process and action of the family to cooperate with the environment to increase their financial resources. But the economic dimension is the lowest dimension 
(42.4\%) with "helping to sell the work of the village community through activities that are followed" as the lowest statement $(13.3 \%)$, as well as the highest statement that determines "the use of family planning tools as a contribution to manifest FP villages" (74.7\%). These results indicate that less than a quarter of the families have not been able decided to promote products of the villager. However, more than two-thirds of families can contribute to creating FP villages with the decision-making that is used to use family planning tools to control the rate of population growth.

\section{Family Transaction Value with Its Environment}

The value of family transactions in this study consists of six dimensions, namely community cohesion, social capital, social strength, obedience, caring, attention and protection. Value is the families perspective with their environment (Melson, 1980 in Sunarti, 2009).

Table 2 Average of family transactions value with its environment index

\begin{tabular}{lr}
\hline Statement & Index \\
\hline Community cohesion & 86.1 \\
\hline Friendly & 89.3 \\
Harmony & 90.9 \\
Familiarity & 81.2 \\
Solidarity & 85.8 \\
Tolerance & 83.3 \\
\hline Social capital & 77.1 \\
\hline Trust the people & 65.1 \\
Teamwork & 83.8 \\
Support programs in the community & 82.6 \\
\hline Social strength & 83.3 \\
\hline Help and share to the needy & 90.6 \\
Donating to community activities & 82.7 \\
Participating in community activities & 76.6 \\
\hline Obedience & 89.1 \\
\hline Be obedient to the religion for it is the foundation of life & 95.6 \\
Be obedient to the norms & 85.8 \\
Be obedient to the leader & 86.1 \\
\hline Caring & 91.2 \\
\hline Care about environmental safety & 90.2 \\
Care about the beauty of the environment & 90.9 \\
Care for environmental cleanliness & 92.5 \\
\hline Attention and protection & 89.9 \\
\hline Mutual attention and protect the children & 95.1 \\
Mutual attention and protect the teenagers & 84.1 \\
Mutual attention and protect the elderly & 90.6 \\
\hline Family transactions value total & 86.1 \\
\hline
\end{tabular}

Table 2 shows that the transaction value of families with its environment in the high category $(86.1 \%)$. The dimensions of community cohesion are indicated to be relatively good $(86.1 \%)$ with the lowest statement that is "tolerance" $(83.3 \%)$, and the highest is "harmonious" (90.9\%). These results show that respecting differences or tolerance within the environment can be improved well because harmony is a crucial thing for the family. The results show the dimensions of social capital is the lowest dimension in family transaction value $(77.1 \%)$ with the highest statement is "cooperation" (83.8\%), and the lowest statement is "trusting the people" (65.1\%). These 
results show that more than half of the families when conducting transactions with its environment consider it not so important to believe in citizens, but still do cooperation with their environment which is considered necessary. Social strength categorized as high (83.3) with the highest statement "helping and sharing to the poor" (90.6\%) and the lowest statement is "participating in community activities" (76.6\%). Table 2 shows that family obedience is relatively good $(89.1 \%)$. The statement of "obedient to the religion for it is the foundation of life" is higher (95.6\%) than "obedient to the norms" (85.6\%) and the leader $(86.1 \%)$. Based on the six dimensions of transaction value, it is known that the dimension of caring is the highest dimension (91.2\%) with the highest statement is "care for the environmental cleanliness" (92.5\%) and "care for environmental safety" is the lowest statement $(90.2 \%)$. The results showed that the dimensions of attention and protection were relatively good $(89.9 \%)$ with the highest statement of "mutual attention and protect the children" (95.1\%) and the lowest statement "pay attention to each other and protect the adolescents" $(84.1 \%)$. These results indicate that families pay more attention and protect children than teenagers and the elderly.

\section{Family Social Strength}

Family social strength is an excellent coping mechanism, oriented towards religious values, effective in communicating, maintaining and increasing family commitment, maintaining social relations, and the ability to cope with crises (Sunarti, 2013).

Table 3 Average family social strength index

\begin{tabular}{lr}
\hline Statement & Index \\
\hline Self Esteem dimension & 57.1 \\
\hline The family devout to worship & 73.6 \\
The family can see the good side of every phenomenon & 70 \\
When in trouble, the family is sure to be helped by the environment & 50.2 \\
The family believe that the environment will help to solve the problem & 39.7 \\
The family take the initiative to seek advice from trusted ones & 43.3 \\
The family initiate to care and discuss the environment's issues & 66.3 \\
\hline Social spirit dimension & 68 \\
\hline The Family active to participate in social activities & 60.2 \\
The Family active to build a good social networking & 66.9 \\
The Family obedient and discipline on norms & 71.6 \\
The Family feel happy to communicate with the neighbors to establish a & 73.3 \\
relationship & 61.5 \\
\hline Family social strength total
\end{tabular}

Table 3 shows that family social strength is categorized as being $(61.5 \%)$. The dimension of social spirit is the highest dimension (61.5) with the highest statement " the family feel happy to communicate with neighbors to establish a relationship" $(73.3 \%)$, and the lowest statement "the family active to participate in social activities" $(60.2 \%)$. The self-esteem dimension is the lowest dimension $(57.1 \%)$ with the lowest statement that "the family believe that the environment will help solve the problem" (39.7\%) and the highest statement "the family devout to worship" (73.6\%). These results show that almost half of the families are not convinced with environmental assistance and have not entirely taken the initiative to ask suggestion if there are problems. 


\section{Correlation}

The results of the correlation test showed a significant positive relationship between social strength and the wife's education $(r=0.227, p=0.05)$. The higher the wife's education will increase the family social strength. Family social strength is significantly negative related to the number of children $(r=-0.272, p=0.01)$ and family size $(r=-0.188, p=0.05)$. The more children and family members one has can degrade family social strength. Furthermore, there is a significant positive relationship between family social strength and community cohesion $(\mathrm{r}=0.289, \mathrm{p}=0.01)$, social capital $(\mathrm{r}=$ $0.372, p=0.01)$, obedience $(r=0.246, p=0.01)$, caring $(r=0.297, p=0.01)$, economic dimension $(\mathrm{r}=0.356, \mathrm{p}=0.01)$, and the social community $(\mathrm{r}=0.569, \mathrm{p}=0.01)$. The higher community cohesion, social capital, obedience, and caring will improve family social strength. Likewise, the greater the families decision about the economic and social community will strengthen the family. The data in Table 4 also shows that total decision-making $(r=0.562, p=0.01)$ and total transaction value $(r=0.357, p=0.01)$ is positively associated with family social strength. The higher the family decision-making and transactions value with its environment can develop the family social strength.

Table 4 The result of correlation test

\begin{tabular}{|c|c|c|c|}
\hline Variable & $\begin{array}{l}\text { Decision- } \\
\text { making }\end{array}$ & Transaction Value & $\begin{array}{l}\text { Family Social } \\
\text { Strength }\end{array}$ \\
\hline \multicolumn{4}{|l|}{ Family characteristics } \\
\hline Wive's age (year) & -0.005 & 0.056 & -0.051 \\
\hline Husband's age (year) & -0.046 & -0.023 & -0.044 \\
\hline Wife's level education (year) & 0.006 & 0.176 & $0.227 *$ \\
\hline Husband's level education (year) & -0.030 & -0.060 & 0.147 \\
\hline Income (rupiah) & -0.021 & -0.099 & 0.113 \\
\hline Number of families & -0.143 & -0.055 & $-0.188 *$ \\
\hline Length of stay (year) & 0.061 & 0.096 & 0.051 \\
\hline Marriage age (year) & -0.061 & 0.077 & -0.158 \\
\hline Number of children & -0.133 & 0.000 & $-0.272 * *$ \\
\hline Decision-making total & & $0.319 * *$ & $0.562 * *$ \\
\hline Economic dimension & & 0.169 & $0.356^{* *}$ \\
\hline Social community dimension & & $0.333 * *$ & $0.569 * *$ \\
\hline Transaction value total & $0.319 * *$ & & $0.357 * *$ \\
\hline Community cohesion & $0.240 * *$ & & $0.289 * *$ \\
\hline Social capital & $0.315 * *$ & & $0.372 * *$ \\
\hline Social strength & 0.159 & & 0.169 \\
\hline Obedient & 0.145 & & $0.246^{* *}$ \\
\hline Caring & $0.274 * *$ & & $0.297 * *$ \\
\hline Attention and protection & 0.067 & & 0.118 \\
\hline
\end{tabular}

\section{Influence of Family Characteristics, Decision-Making, Transaction Value with Its Environment and Family Social Strength}

The results of regression tests (Table 5) were carried out using four models aimed at analyzing the patterns of influence of total and per-dimensional variables with and without family characteristics. 
Table 5 Result of regression test

\begin{tabular}{|c|c|c|c|c|}
\hline & Variable & Unstandarized $(\beta)$ & Standarized $(\beta)$ & Sig \\
\hline \multirow{4}{*}{ Model 1} & Constant regression & 10.009 & & 0.795 \\
\hline & Decison-making & 0.694 & 0.541 & $0.000 * *$ \\
\hline & Transaction value & 0.329 & 0.215 & $0.004 * *$ \\
\hline & F / Adj. R Square / Sig. & \multicolumn{2}{|c|}{$36.72 / 0.375 / 0.000 * *$} & \\
\hline \multirow{13}{*}{ Model 2} & Constant regression & 13.295 & & 0.376 \\
\hline & Wife's age (year) & -0.347 & -0.137 & 0.344 \\
\hline & Husband's age (year) & 0.278 & 0.121 & 0.330 \\
\hline & Wife's level education (year) & 0.892 & 0.148 & 0.107 \\
\hline & Husband's level education (year) & 0.410 & 0.074 & 0.413 \\
\hline & Income (rupiah) & $-1.856 \mathrm{E}-6$ & -0.056 & 0.470 \\
\hline & Number of families & 3.419 & 0.253 & 0.120 \\
\hline & Length of stay (year) & -0.029 & -0.019 & 0.807 \\
\hline & Marriage age (year) & 0.070 & 0.025 & 0.839 \\
\hline & Number of children & -5.487 & -0.374 & $0.028 *$ \\
\hline & Transaction value & 0.304 & 0.198 & $0.008 * *$ \\
\hline & Decision-making & 0.683 & 0.533 & $0.000 * *$ \\
\hline & F / Adj. R Square / Sig. & \multicolumn{2}{|c|}{$8.822 / 0.420 / 0.000 * *$} & \\
\hline \multirow{10}{*}{ Model 3} & Constant regression & 11.423 & & 0.575 \\
\hline & Economic dimension & 0.120 & 0.101 & 0.240 \\
\hline & Social community dimension & 0.502 & 0.456 & $0.000 * *$ \\
\hline & Community cohesion & 0.106 & 0.092 & 0.418 \\
\hline & Social capital & 0.117 & 0.167 & 0.128 \\
\hline & Social strength & -0.076 & -0.060 & 0.521 \\
\hline & Obedience & 0.016 & 0.013 & 0.906 \\
\hline & Caring & 0.146 & 0.109 & 0.316 \\
\hline & Attention and protection & -0.108 & -0.075 & 0.468 \\
\hline & F / Adj. R Square / Sig. & \multicolumn{2}{|c|}{$9.974 / 0.376 / 0.000 * *$} & \\
\hline \multirow{19}{*}{ Model 4} & Constant regression & 14.438 & & 0.999 \\
\hline & Wife's age (year) & -0.470 & -0.185 & 0.209 \\
\hline & Husband's age (year) & 0.317 & 0.138 & 0.297 \\
\hline & Wife's level education (year) & 1.175 & 0.195 & $0.039 *$ \\
\hline & Husband's level education (year) & 0.196 & 0.036 & 0.267 \\
\hline & Income (rupiah) & $-2.373 E-6$ & -0.071 & 0.363 \\
\hline & Number of families & 3.342 & 0.248 & 0.138 \\
\hline & Length of stay (year) & -0.075 & -0.051 & 0.538 \\
\hline & Marriage age (year) & 0.399 & 0.143 & 0.274 \\
\hline & Number of children & -6.503 & -0.443 & $0.010^{*}$ \\
\hline & Economic dimension & 0.105 & 0.089 & 0.306 \\
\hline & Social community dimension & 0.492 & 0.447 & $0.000 * *$ \\
\hline & Community cohesion & -0.004 & -0.003 & 0.976 \\
\hline & Social capital & 0.236 & 0.223 & $0.045^{*}$ \\
\hline & Social strength & -0.140 & -0.111 & 0.255 \\
\hline & Obedience & 0.023 & 0.018 & 0.865 \\
\hline & Caring & 0.227 & 0.169 & 0.122 \\
\hline & Attention and protection & -0.102 & -0.071 & 0.498 \\
\hline & F / Adj. R Square / Sig. & \multicolumn{2}{|c|}{$6.445 / 0.438 / 0.000 * *$} & \\
\hline
\end{tabular}

Note: $(* *)$ significance on $\mathrm{p}<0.01 ;(*)$ significance on $\mathrm{p}<0.05$

The first model regression shows that the transaction value has a significant positive effect on family social strength with an Adjusted R Square value of 0.375. The 
second model shows the transaction value (0.008) and decision making (0.000) has a significant positive effect on family social strength with an Adjusted R Square value of 0.420 , so the higher transaction value and family decision making with the environment will strengthen the family strength. However, the number of children had a significant negative effect on family social strength with a beta value of -5,487 meaning that if the variable of the number of children added 1 point, it will reduce the family social strength by 5.487 points. The third model of regression test shows that the social community (0.000) has a significant positive outcome on family social strength thus any increase in decision making in the social community will increase the family social strength with the Adjusted R Square value of 0.376. The fourth model of the regression test shows that the wife's education (0.039), social capital $(0.045)$, and the social community dimension (0.000) have a significant positive effect on family social strength. However, the number of children (0.010) has a significant negative effect on family social strength. These results indicate that every increase in wife's education, social capital, social community, and the fewer number of children will increase the family social strength with the value of Adjusted R Square 0.438.

Based on the results of the regression test on the four models, the Adjusted $\mathrm{R}$ Square value was obtained between $0.375-0.438$ percent. These results indicate that the four regression models only explain 37.5-43.8 percent, the rest is influenced by other variables which is not examined in the study.

\section{Discussion}

Family social strength can be achieved optimally as an effort to obtain the best quality family transactions with its environment as a reflection of the well-functioned of family ecosystems (Melson, 1980). The results showed that the family social strength was categorized as being moderate because family social strength had not been optimal, which allegedly contributed to family participation in the community. According to Sunarti and Fitriani (2010) stated that high family social strength is related to strong inter-community relations. The current development of technology and information can make families stronger in their relationships with their environment as Ruiz et al. (2017) stated that information technology is a way to create space to interact with people who are far closer, thus families can contribute in boost networking with its environment.

The dimension of social spirit in family social strength is the highest dimension indicated by the statement of families are happy to communicate with their neighbors to create a good relation and also in order to strengthen the family. According to Weiss et al. (2017) showed that social support will be the mediator of the relationship between stress and hardiness. As Sun et al. (2018) also stated that social support, sharing information, and getting to know each other between ages in the environment can reduce the stress that family experienced. These results show social strength can help families deal with vulnerabilities that occur in every stage of development. Family social strength becomes a positive development to obtain psychological balance under the dynamics of life (Wang et al., 2014). In the dimension of social spirit, the statement shows that family rarely participates in social activities in the environment. These results are in line with the value of family transactions in the dimension of family social strength which is shown that family participation in the community activities is low. These results are thought to be caused by several factors, namely work that cannot be left and child-rearing at home. These results are also thought to contribute to moderate categorical social strength. The dimension of self-respect for family social strength is 
the lowest dimension with family statements convinced that the environment will help solve problems. According to Sunarti and Fitriani (2010) stated that the level of trust can be seen from the level of a person's beliefs, agreements, and consistent actions when there is a relation between a person or group and the community environment.

Social strength is related to decision-making and the value of family transactions with its environment. Family values as dependence on family members can influence decision-making to meet needs and desires in order to achieve prosperity (Lucifora \& Meurs, 2012). The results of the correlation also show that the higher the wife's education, the greater the family social strength. These results allegedly educated wife would be easier to socialize and contribute well to their environment. This result is in line with research conducted by Fatwa (2014) which states that higher education of wives can improve family welfare. The results of regression tests indicate that the value of family transactions with the environment has a significant positive effect on family social strength. Families that still have values such as the source of happiness, comfort, and tranquility, a place to share joy and sorrow (Larasati, 2013) are the basis for the family transactions with its environment.

Family decision making with the environment is a process of family interaction that reflects and influences patterns of power, authority, communication, and conflict in the family itself that are influenced by family life (Sunarti, 2009). The study determines that family decision-making with its environment in the medium category with the highest statement is found in the social community dimension particularly allowing children to play with the environment without distinguishing social status. These results consist with research of Lestari (2012) that through transactions with the environment, children can get ideas and knowledge in the environment to optimize their abilities. These results were also supported by Robert et al. (2016) shows that there is a significant relationship between active children and a good neighborhood. The economic dimension is the dimension with the lowest achievement on family decisionmaking. The results showed that less than a quarter of the families helped sell the work of the village community and only a quarter of the families collaborated with the environment to supplement their income. According to Herawati et al. (2018) found neighboring support in the form of instrumental and information among wives still low, for instance exchanging ideas and helping with problems with neighbors or the environment. According to Kusumo et al. (2009) state that better decision-making is carried out jointly among family members both in the fields of education, health, strategies for fulfilling needs, family needs, and social societies. The results of the study found that family decision-making with the environment in improving economic function was still not optimal. According to Nurillah (2013) states that family strength is influenced by economic pressure and coping strategies. The low mutual trust in the value of the transaction thought to contribute to the family decision-making in an economic dimension that is not optimal. In fact, low mutual trust in society has an impact on social problems such as social and economic vulnerability (Fadli, 2007). However, in the economic dimension, there is the highest statement, namely determining the use of family planning tools as a contribution to manifest the KB village. The existence of family participation related to the use of family planning devices is thought to be influenced by the value of family transactions, namely mutual attention and protect the children who are high on the dimensions of attention and protection. The correlation result shows that the bigger of family size the lower family's social strength, meaning that FP program worked well. Besides that, family social 
strength influenced positively by family's decision making, regression result shows. According to Walsh (1998) in Siahaan (2012) states that social strength consists of system beliefs, family organization patterns, and communication processes in which a decision-making process is carried out to achieve family goals. Families that function well and children who grow and develop healthily have a good kinship with the environment that involves caring and commitment relationships (Walsh, 2002). The more children a family has can reduce social strength. Families with more toddlers tend to stay in the house to take care of children so that families are less actively participating and involved in social activities with the environment. According to Maryanti (2016), there are still many families who are reluctant to actively participate in association activities for they prefer to focus on child-rearing and families. On the transaction value, it is also known that the statement protecting children has a high category. This is believed to be the reason families prefer to take care of children in the house rather than being involved in social activities in the environment.

Family's transaction value with its environment is an individual's conception of interests (important-not important) between family and environment (Melson, 1980). The value in family life becomes a structured process for the relationship of family members as individuals (Puspitawati, 2013). The results of the research show that the value of family transactions with its environment categorized as high. The dimension of caring is the highest dimension with statements caring about environmental cleanliness. These results are supported by statements that contribute to maintaining a relatively good environmental cleanliness in the social dimension of the family decision-making with the environment. These results are consistent with the result of Aprianto (2008), show that there is a concern of citizens in an area towards the environment such as cleanliness, comfort, and beauty. This is conceived to be based on awareness and maintenance of resources that can provide welfare to every citizen. According to Suandi (2007) states that more than 50 percent of the community has a high character such as the sensitivity of the community to the progress of the village and help each other with the environment. The dimension of social capital in transaction value is the lowest dimension with a statement of excellent cooperation and a profound statement of trust in citizens. These results are in line with the research of Sunarti and Fitriani (2010); Achmad (2014) that besides high trust in the community such as helping each other, there are still people who have low levels of trust regarding finance, information obtained, and conversations that sometimes do not match reality. The average results of the dimensions of social capital are in line with the results of the lowest index average of family social strength, namely families believe that the environment will help solve problems. The low level of trust is estimated contributing to making the family uncertain to the neighbors in solving problems. Though trust is the basis for individuals to interact and establish good relations with the environment because there are underlying values (Syawie, 2007). According to Gurieva (2016) states that in a social environment, trust is the basis of building cooperation, maintaining relationships, and communicating.

Meanwhile, the transaction value shows the highest statement is obedience to the values and teachings of religion as the basis of life, as well as the family social strength that is the obedient family to worship. These results show that families carry out religious functions known from family members who maintain religious values and carry out religious activities as the 2015-2019 BKKBN Strategic Plan related to the empowerment of 8 family functions. Internalization of ethical values in the family can 
be done through the application of religious values to shape children's behavior in socialize with the environment (Dermawan et al., 2017), as well as being a force for families to play their essential role in parenting (Madden et al., (2014).

Family transactions with its environment are part of the family ecology in which there is a reciprocal relationship between family and environment. A family environment is a place where families carry out an interaction process to reach qualified and dependable individuals in everyday life. Decision-making and the value of family transactions with an increasingly great environment will improve family social strength. The family social strength in neighborhoods can contribute to the realization of a family-friendly environment. The construction of family-friendly areas is a development effort carried out by various parties, both government and non-government, which causes the region to have a natural carrying capacity and high environmental capacity (Sunarti, 2015). This is done as an effort to realize families that can carry out their roles well as safe, prosperous and harmonious human resource development and neighborhood environment.

\section{Conclusion and Recommendation}

\section{Conclusion}

The results showed that most of the age of husband and wife were in the early adult category (18-40 years). Family decision making with its environment in the medium category. Majority of the respondents allowing children to play with the environment and teaching them not to differentiating social status. The value of family transactions with its environment in the high category with the highest achievement is the dimension of caring for the statement of paying attention and protecting the child. The family social strength of the medium category with the highest achievement, namely the dimension of social spirit in the statement the family likes to communicate with neighbors builds good relations and the lowest achievement. The four models of a regression test, both with and without family characteristics consistently show the value of transactions and decision-making have a positive effect on family social strength. Meanwhile, the family characteristics of the number of children both with and without the dimensions of transaction value and the dimensions of decision-making consistently have a negative effect on family social strength.

\section{Recommendation}

Based on the results of the research related to decision-making and the value of family transactions with its environment, researchers suggested to families to increase their contribution and social involvement with the environment in order to have high social strength. For academics and researchers, it can be used as advanced research in an ecological study and family strength, as well as an idea for further research to examine family transactions with the environment from the perspective of families that have school-age children, adolescents, adults, or the elderly. For the management of Pasirjaya Subdistrict, institutions, as well as communities engaged in the social sector can increase family support to transact with their environment actively in building social strength, also to create a family-friendly environment. As well as for the government, it can provide additional information in conducting family empowerment programs and 
public policy making related to the family-friendly environment in realizing family strength.

\section{References}

[BPS] Badan Pusat Statistik. (2015). Kota Bogor dalam Angka 2017. Jakarta (ID): Badan Pusat Statistik.

[BPS] Badan Pusat Statistik. (2016). Indeks Pembangunan Teknologi Informasi dan Komunikasi Indonesia. Jakarta (ID): Badan Pusat Statistik.

Achmad, R.V.S. (2014). Modal Sosial, Dukungan Sosial, dan Ketahanan Sosial Keluarga di Daerah Pemukiman Marjinal Kota Bogor (thesis). Bogor (ID): Institut Pertanian Bogor.

Aprianto, Y. (2008). Tingkat Partisipasi Warga dalam Pengelolaan Lingkungan Berbasis Masyarakat (thesis). Bogor (ID): Institut Pertanian Bogor.

[BKKBN] Badan Kependudukan dan Keluarga Berencana Nasional. (2015). Rencana Strategis Badan Kependudukan dan Keluarga Berencana Nasional Tahun 20152019. Jakarta (ID): BKKBN.

Dermawan, S., Sunarti, E., Herawati, T. (2017). Internalisasi Nilai Kebaikan Melalui Fungsi Keagamaan dan Pengondisian Lingkungan dan Dampaknya terhadap Karakter Anak. Jurnal Ilmu Keluarga dan Konsumen 3(10): 204-215.

Fadli. (2007). Peran Modal Sosial dalam Percepatan Pembangunan Desa Pasca Tsunami: Kasus Pembangunan Perumahan dan Peningkatan Pendapatan Keluarga di Beberapa Desa di Kabupaten Aceh Besar (thesis). Bogor (ID): Institut Pertanian Bogor.

Fatwa, N. (2014). Kepadatan, Kesesakan, Privasi, dan Kesejahteraan Subjektif Keluarga di Pemukiman Marjinal Kota Bogor (thesis). Bogor (ID): Institut Pertanian Bogor.

Gurieva, S., Borisova, M., Mikhalyuk, J., Dmitrieva, V., Kawabata, T. (2016). Trust as a Mechanism of Social Regulation the Moder Youth's Behavior. American Journal of Applied Sciences 13(1): 100-110. Tersedia di: http://thescipub.com/abstract/10.3844/ofsp.10410

Herawati, T., Kumalasari, B., Musthofa, Tyas, F.P.S. (2018). Dukungan Sosial, Interaksi Keluarga, dan Kualitas Perkawinan Pada Keluarga Suami Istri Bekerja. Jurnal Ilmu Keluarga dan Konsumen 11(1):1-12.

Kusumo, R. B., Sunarti, E., Pranadji, D.K. (2009). The role of gender in family welfare of paddy and horticulture farmers in the suburban area. Media Gizi \& Keluarga 32(2): 52-64.

Larasati, R. N. (2013). Nilai-Nilai Keluarga, Interaksi Keluarga, dan Potensi Perdagangan Manusia (Kasus di Kabupaten Cianjur) (thesis). Bogor (ID): Departemen Ilmu Keluarga dan Konsumen, Fakultas Ekologi Manusia, Institut Pertanian Bogor. Bogor.

Lestari, S. (2012). Psikologi Keluarga. Penanaman Nilai dan Penanganan Konflik dalam Keluarga. Jakarta (ID): Kencana Prenada Media Group.

Lucifora, C., Meurs, D. (2012). Family Values, Social Needs and Preferences for Welfare. Discussion Paper No. 6977.

Madden, E. E., Aguiniga, D. M., Zellman, K. T. (2014). Religious Faith and Depression Among Child Welfare Involved Mothers with Young Children. Journal of Family Strengths 14(7): 1-20. 
Maryanti. (2016). Modal Sosial, Dukungan Sosial, dan Ketahanan Sosial Keluarga di Rusunawa Jatinegara Barat (thesis). Bogor (ID): Institut Pertanian Bogor.

Melson, G. F. (1980). Family and Environment. Burgess Publishing Company. Minneapolis, Minnesota (USA).

Nurillah, H. (2013). Strategi koping, tekanan ekonomi dan ketahanan keluarga di kawasan kumuh (thesis). Bogor (ID): Institut Pertanian Bogor.

Puspitawati, H. (2013). Ekologi Keluarga Konsep dan Lingkungan. Bogor (ID): IPB Press.

Robert, J. D., Knight, B., Ray, R., Saelens, B. E. (2016). Parental Perceived Built Environment Measures and Active Play In Washington DC Metropolitan Children. Journal Preventive Medicine Reports 3: 373-378.

Ruiz, K. .R, Sáncheza, L. E., Plataa, J. P., Giraldo, S. V., Cardonaa, M. A., Avendañoa, C. H., Arias, A. V., Piedrahita, L. B. (2017). Information and Communication Technologies Impact on Family Relationship. Journal Social and Behaviour 237: 30-37.

Siahaan, R. (2012). Ketahanan sosial keluarga: Perspektif pekerja sosial. Jurnal Sosioinformasi 17(2).

Suandi. (2007). Modal sosial dan Kesejahteraan Keluarga di Daerah Perdesaan Propinsi Jambi (thesis). Bogor (ID): Institut Pertanian Bogor.

Sun, Y., Phillips, D. R., Dan Wang, M. (2018). A Study of Housing Typology and Perceived Age-Friendliness in an Established Hong Kong New Town: A PersonEnvironment Perspective. Journal Geoforum 88: 1-27.

Sunarti, E. (2001). Ketahanan keluarga dan pengaruhnya terhadap kualitas kehamilan (thesis). Bogor (ID): Institut Pertanian Bogor.

. (2007). Ekologi Keluarga. Di dalam: Adiwibowo S. Ekologi Manusia. Bogor (ID): Institut Pertanian Bogor.

(2009). Ekologi Keluarga: Sejarah, Konsep, dan Tantangan Penelitian. Dalam Sunarti E., Naskah Akademis. Pengembangan Model Ecovillage. Pembangunan Kawasan Perdesaan serta Sumbangan Pertanian Bagi Peningkatan Kualitas Hidup Penduduk Perdesaan. Bogor: Crespent Press. hlm 178-192. . (2013). Ketahanan Keluarga. Bogor (ID): Institut Pertanian Bogor. . (2015). Ketahanan Keluarga Indonesia: Dari Kebijakan dan Penelitian Menuju Tindakan. Buku disajikan pada Orasi Ilmiah Guru Besar IPB yang diselenggarakan oleh Institut Pertanian Bogor. . (2017). Pembangunan Wilayah Ramah Keluarga. Tidak dipublikasikan.

Sunarti, E., Fitriani. (2010). Kajian Modal Sosial, Dukungan Sosial, dan Ketahanan Keluarga Nelayan di Daerah Rawan Bencana. Jurnal Ilmu Keluarga dan Konsumen 3(2): 93-100.

Syawie, M. (2007). Peran Kelompok Sosial dalam Penguatan Ketahanan Sosial (Sebuah Kajian Modal Sosial di Desa Abiansemal, Kecamatan Abiansemal, Kabupaten Badung, Bali). Jurnal Penelitian dan Pengembangan Kesejahteraan Sosial 12(1): 45-51.

Walsh, F. (2002). A Family Resilience Framework: Innovative Practice Applications. Family Relation 51(2):130-138

Wang, P., Liu, D., Zhao, X. (2014). The Social Ecology of Resilience: A Comparison of Chinese and Western Researches. Journal of Social and Behavioral Sciences 116: 3259-3265. 
Weiss, J. A., Robinson, S., Fung, S., Tint, A., Chalmers, P., Lunsky, Y. (2017). Family Hardiness, Social Support, and Self-Efficacy in Mothers of Individuals with Autism Spectrum Disorders.Journal research in autism spectrum disorder. 